\title{
Legal Protection of Foreign Investment (FI) in Zanzibar: Lesson for China Investments
}

\author{
Naumi Kassim Mohammed ${ }^{\circledR}$, Dexiang Guo*, Yongyeh Ngalim Elizabeth \\ School of Law, Zhengzhou University, Zhengzhou, China \\ Email: ummymahad@yahoo.com, ^dexiangguo@sina.com, yongyehelizabeth97@gmail.com
}

How to cite this paper: Mohammed, N. K., Guo, D. X., \& Elizabeth, Y. N. (2021). Legal Protection of Foreign Investment (FI) in Zanzibar: Lesson for China Investments. Beijing Law Review, 12, 1191-1214. https://doi.org/10.4236/blr.2021.124062

Received: August 22, 2021

Accepted: December 17, 2021

Published: December 20, 2021

Copyright (อ 2021 by author(s) and Scientific Research Publishing Inc. This work is licensed under the Creative Commons Attribution International License (CC BY 4.0).

http://creativecommons.org/licenses/by/4.0/ (c) (i) Open Access

\begin{abstract}
Most countries around the world, including Tanzania (Zanzibar as a part) sought to establish the proper legal framework in attracting and protecting foreign investments. The enactment of Local Investment Legislations and signing of Bilateral Investment Treaties (BITs) are among the primary tools for achieving the aforementioned goal. The participation of a state into international investment treaties, as well as the ratification of conventions into domestic legislation, makes the protection measures part of their legal structure. Their significance stems from the fact that they contribute to access to justice for foreign investors, hence creating a favorable environment for foreign investments. This article's objective is to examine the legal framework related to the protection of foreign investments in Zanzibar. In doing so, the article examines the laws responsible for the protection and whether those laws are strong enough for such protection, challenges foreign investors may face and the opportunities for foreign investors especially the Chinese. The study has however established that, the laws are inadequately strong, and therefore the protection is somehow ineffectual. As a result, there is a need for legislative amendments and updates for an effectively protection of foreign investments and their reassurance in the event of any apprehension especially currently where Tanzania has begun the process of regulating its foreign investment regime by passing laws that exclude international arbitration.
\end{abstract}

\section{Keywords}

Foreign Investments, Foreign Investors, Legal Framework, Legal Protection, Zanzibar

\section{Introduction and Conceptual Framework}

\subsection{Introduction}

As provided by Gabagambi (2013), Tanzania, of which Zanzibar is a part, has 
been undergoing various economic reforms since 1986 with the goal of transitioning the economy from a centralized, publicly owned to a market-driven and private-sector-led one. The major policy and structural reforms carried out played a significant role in improving the business and investment environment in the country as provided by Tanzania Investment Centre's Social Accountability Session Report (2012). The Report (2012) explained further that the governments do this mainly through putting favorable policies in place, provision of a conducive investment environment for local and foreign investment.

About the Government's stability, the Zanzibar Investment Promotion Authority (ZIPA) is on the view that, Zanzibar's government is politically stable, economically and socially advantageous, and it enthusiastically welcomes international investors. There is no threat of seizure or nationalization. The government, through its Constitution and International Conventions agrees to protect foreign investors' interests; and allows 100 percent foreign ownership as well as free repatriation of profits. Further, investors in Zanzibar can access into the East African and SADC markets, take advantage of EU export restrictions, and gain access into the US market through AGOA as per UNCTAD/ITE/IPC/Misc.9.

The government also provides Regional and International market concessions and also tries its best to establish an improved business environment in the region. The Government offers the firms conditions of open market and regulatory flexibility environment in these regions. To attract more foreign investments, UNCTAD/ITE/IPC/Misc.9 is on the view that, the Zanzibar government created an actual legal framework for the protection of foreign investments where there is no distinction between protection for investors from foreign countries and protection for indigenous.

\subsection{Justification of the Subject}

China is acknowledged worldwide for making great and quick stride in three main areas for economic development. According to China's Economic Rise: History, Trends, Challenges, and Implications for the United States (July 12, 2006-June 25, 2019), those areas are the economic growth that enables China to accumulate substantial sovereign capital; the technological development that sustains its economic growth and positions it in a strategic position in the world diplomacy and politics. Economic growth has enabled China to make substantial foreign investments throughout the world where as Africa (including Zanzibar) is a major destination of investment for Chinese investors. This is provided by Saïd, Myriam Dahman (2013) and China's Economic Rise: History, Trends, Challenges, and Implications for the United States (July 12, 2006-June 25, 2019).

Zanzibar on the other hand has its own executive system with the Judiciary system and Parliament (House of Representatives) which passes the laws applicable in Zanzibar (non union matters) as provided by Investment Climate Statements (2020) as well in The African Democracy Encyclopedia Project (Up- 
dated September 2010). In line of that, investment issues according to Investment Climate Statements (2020) are among the non-union matters. As a result, each part of the union deals with itself in this regards. Zanzibar has its own foreign investment laws, which are administered by the House of Representatives (although taxation is the responsibility of the union). Zanzibar is also regarded as among the best foreign investment destinations in Africa, and there are numerous reasons for investors to focus their efforts in the region, given its political, social, and economic stability, as well as the fact that private investments are protected by the constitution as viewed by the Investment Climate Statements (2020).

This paper aims to thoroughly unveil the Zanzibar's policy; legal and administrative regime pertaining to foreign investments for the rationale of enabling Chinese investors understands the current condition. Further, this study will serve as window of seeing or contemplating the investment regime in Zanzibar for Chinese investors.

\section{Overview of Foreign Investments in Tanzania}

Many countries whether developed or developing ones have made protecting foreign investment a top priority. For Gagné (2019) this goal has primarily been achieved through the negotiation and signing of BITs. In line of that, Tanzania (where Zanzibar is a part) has committed itself to many international treaties and agreements as per United Nations (2004). Tanzania is also a WTO member nation and, subject to investment-related obligations under the Trade in Services and Investment Measures Trade-Related General Agreement as stated by United Nations (2004). The OECD (5-6 December 2002) has proved that Tanzania is a several World Bank conventions member, such as the "International Centre for the Investment Disputes Settlement" (ICSID) and the "Multilateral Investment Guarantee Agency" (MIGA).

\subsection{The Historical Perspective of Tanzania Mainland's Foreign Investments}

The former Tanganyika also known as Tanzania mainland has made numerous attempts since its independence in 1961 to establish the necessary policy and legal frameworks for economic growth. In regards to foreign investments in Tanzania, it is contended by Maina (1994) that, the country only had a favorable attitude toward foreign investments during the first six years of independence. According to Neerso (1972), Tanzania's First Five Year Plan (1964-1969) projected that total central government development expenditure would be Tanzania shillings 2040 million of which Tshs. 1590 million would be financed by foreign sources and local sources which is also provided by Bukuku (1993). Available data given by Neerso (1972) indicates that this figure was less than a third of what actually happened in the actual development of the country.

Further in Rugumamu (1988), the government expected foreign and local in- 
vestors to play a major part in the industrial development of the country whilst Nyerere (1966) indicated that, it is also in this context that the late President of Tanzania Mwalimu Nyerere while addressing the meeting of the Eastern Africa Association of Chamber of Commerce on 11th February 1963 told the participants that; "The government wishes to work with private investors for the development of Tanganyika". He also stated in 1964 that he was determined to have an oil refinery in Tanzania rather than continue to import the end products crude oil. Nyerere repeated the same in two years later, on February 111965 when he laid the foundations for the ENI oil refinery as stated by Ajl (2020).

In 1963 for Maina (1994), the Tanzanian government prepared and passes the Foreign Investment (Protection) Act (1963). According to Tanganyika Gazette, (1963) the intention of this legislation was to offer statutory guarantees to foreign investors. The government also went into bilateral agreements with foreign governments to foster investment promotion and protection. The United States, Germany, Switzerland, the Netherlands and the Confederation of Swiss all signed agreements with the Tanzanian Government which included notes Exchange Composing a United States-Tanganyika agreement in relation to Investments Guarantees of 14th November 1963 as stated in Tanganyika Gazette, (1963).

For Rahim (1968), the Arusha Declaration of $5^{\text {th }}$ February 1967 took the world by surprise. The then TANU government swiftly enacted laws through which various enterprises were taken over. Those laws in Rahim (1968), affected the enterprises such as Banks, Retail and Wholesale Trade, Agricultural Products Marketing and Insurance.

The takeovers as per James Mittelman (1981) went on until the 1970s and by then, for Bevan, et al. (1987) investors no longer felt safe in the country. When the presidency of Ali H. Mwinyi took over power in 1985, it inherited a half-hearted liberalization of trade and advanced it more as stated by Maina (1988). In United Nations Conference on Trade and Development (2002), the investors had an unpleasant experience before, as they were wary of nationalization. Usiri (2014) further indicates that a serious undertaking by the government in respect to the assurance of private property protection was necessary for them to invest. Deliberate policies for economic liberalization have been instigated and implemented. According to Usiri (2014), reforms have been encountered in the institutions of finance, public sector, civil service and others. The National Investment Act of 1997 was passed aimed at encouraging between domestic and overseas investment.

\subsection{The Historical Background of Foreign Investments in Zanzibar}

The Independent Constitution was formulated after the independence of 1963 (in terms of the Westminster form) while among the special provisions included the Bill of Rights was on the list which created a conducive investment climate, especially to foreigners in as stated by Tanzania Human Rights Jurisprudence 
(2002). Upon revolution, Loimeier (2009) provides that Zanzibar was ruled by Presidential Decree and during that time many properties were confiscated especially those of Arabs. This attitude in Loimeier (2009), it discouraged any form of private initiative and frightened foreigners. Between year 1964 and 1972, the government did everything related to business and politics.

In 1979, as provided by Rainer and Peter (1989), the Constitution was ratified and the proper Judiciary and Legislator also came into being. As indicated in the Constitutional History of Tanzania, the 1984 Constitution was approved in 1984 and the Bill of Rights was entrenched. The economy was liberalized and opened up the gates for investors. In 1986, the Investment Protection Law was enacted where according to Rugumamu (1988) the government liberalized economic activity focused more on private-sector management of the economic activity.

For Gestrin (2006), the Zanzibar Investment Policy was then enacted, stipulating openness to domestic and foreign investment, the right to private ownership and the establishment of businesses, full protection of property rights, a liberalized foreign exchange market, favorable repatriation conditions, a stable and predictable regulatory framework, and the simplification of investment establishment procedures. As a result, foreign investments, especially in tourism, began to grow mainly from Britain, Bahrain, Germany, Mauritius, Italy, Kenya, UAE and South Africa as provided by Jan Mosedale (2011).

\section{Assessment of Laws for the Protection of Foreign Investments in Zanzibar}

\subsection{Background of Zanzibar's Economic and Investment Policies}

On 10th October 1963 as maintained by Article 32 of the Zanzibar Constitution of 1963 as well Suhonen (2009), Zanzibar obtained its independence from the British colonial regime. The Sultan Government was overthrown few weeks thereafter on the 12th January 1963 through a popular revolution according to Karume, Shumbana (2006) while China was amongst the earliest countries in recognition of the revolutionary new regime.

Up to the mid-nineteen eighties, Zanzibar followed a centralized system of economy, in which the government was responsible for the operation and provision of most of economic and social services as stated by the Ministry of Trade and Industry as per the Zanzibar Industrial Policy (2019-2029). The Policy further provides that apart from agriculture, which was totally under the private sector, the remaining economic activities were to a large extent controlled by the government. Beginning 1984, the Government began the process of transforming the Zanzibar economy away from a centralized to liberalized system as what the Zanzibar Investment Policy (ZIP) proves. ZIP stipulates further that the Economic Recovery Programmes of 1986 and 1988, the Zanzibar Investment Protection Act 1986, the Banking and Financial Institutions Act 1991, the establishment of Export Processing Zones in 1992, the establishment of Free-Port facilities in 1998, and the Institution of Fiscal Policy Reform focusing on trans- 
portation were all implemented after the trade liberalization policy. The main goal of numerous changes as ZIP stipulates is to produce a long-term economic climate that can support higher economic growth and lower inflation. ZIP further stated that Zanzibar's government is working to improve the public sector by restoring and preserving infrastructure, enhancing social delivery systems, and increasing government productivity.

In giving the record of the GDP, ZIP is on the view that highest figure in GDP growth rate was recorded in 1996 when it reached 7.2 percent in 2000. The declining contribution of agriculture in both relative and absolute terms has tended to have a negative impact on the growth of GDP. According to ZIP, the government has also introduced a number of steps, including reorganizing the tax structure in order to encourage private investment and grow the revenue base.

\subsection{A Review of Related Framework}

In Tanzania, there exists a widespread belief that the resolution to economic problems will be through foreign investments. Numerous important legal instruments have been enacted in furtherance of this belief as per Bennett \& Mneney (2010). Further, as per 2020 Investment Climate Statements, Tanzania has investment framework agreements in place and offers a variety of incentives and investment promotion services. However, because investment is primarily a non-Union matter, the mainland and Zanzibar have independent laws, rules, and practices except for international investment treaties and tax which are treated as Union matter, and hence apply to both areas. The detailed about Zanzibar's legislative framework for the protection of foreign investments is provided hereunder:-

1) ZIPA.

The Zanzibar Investment Promotion Authority (ZIPA) is a semi-autonomous government entity that operates under Act No. 14 of the Zanzibar Investment Promotion and Protection Authority of 2018. As provided by the Zanzibar Investment Promotion and Protection Act, no. 11 of 2004 and Zanzibar Vision 2020, ZIPA is the primary government institution in charge of promoting and facilitating investment in Zanzibar. Among its duties are; to regulate and adjudicate investment activities in Zanzibar including Free Economic Zones, with proper consideration for the doctrines of openness, competitiveness, and transparency; to promote Zanzibar as an attractive investment, business, and export platform; and to serve as a focal point for investment promotion and facilitation by virtue of Chapter III (3) (v) of the Law No. 11 of Zanzibar Investment Promotion and Protection of 2004.

2) Laws Relating to Business Entities; Companies and other Related Entities.

Zervos, Ndyetabura et al. (2020) indicates that Zanzibar Laws and Regulations allow private sector companies to set up and own their own companies. That is 
to say, foreign investor may choose to establish a foreign company or register a new limited liability company (local company). However, to be allowed to conduct a business in Zanzibar, National Business Portal of Tanzania provides that, an entity must be registered subject to qualifying circumstances under Zanzibar legislations. No entity may operate a business unless it holds a valid business permit issued by the appropriate authorities.

For National Business Portal of Tanzania, The legislation that governs this area is; Zanzibar Business \& Property Registration Agency Act No. 13 of 2012; The Companies Act No. 15 of 2013 and The Company Regulations 2017. The Companies Act No. 15 of 2013 controls the management and operation of Zanzibar-based businesses. Therefore, as per BPRA only when a business is registered in compliance with existing legislation it is legally recognized. There is also The Industrial Property Act No. 4 of 2008 as per the Corporate Registration Guide, Zanzibar (December 28, 2020) which replaced the Patents Decree Chapter157; Industrial Design (Protection) Decree Chapter 158 and The Trademarks Decree Chapter 159. In Peter and Mwakaje (2004), The Industrial Property Act provides adequate protection for IP, patents, Copyright, Trademarks, and Trade Secrets. Thus, foreign investors are able to secure, exercise, and execute exclusive IPR in Zanzibar respectively.

\section{3) Business financing, security and recovery of advances}

Tanzanian laws and regulations (including Zanzibar) permit private sector companies, both domestic and foreign, to establish and own their own businesses and engage in legal forms of remunerative business, as provided by Zervos et al. (2020). The Zanzibar Business and Property Registration Agency (BPRA) is a governmental body established under Act No. 13 of 2012 to handle registration activities and establishes licensing regulations for business operations including Intellectual Property issues as per The Zanzibar Industrial Property Act No. 4 of 2008 and its Regulations. Further, according to the United States Department of State (2008), foreign nationals can obtain loans for domestic capital injection and import of capital goods for domestic use. According to the United States Department of State (2008), the private sector is entitled to a certain number of trade credit instruments, such as documentation (letters of credit), overdrafts, term loans, and guarantees.

\section{4) Immigration and Residence Laws}

The Act No. 7 of 1995 of Immigration, its 1997 Rules and the 1995 Act of Tanzania Citizenship stipulates that foreigners who intend to live and work in Tanzania (mainland and Zanzibar) should acquire a passport and a license. There are charges on the issuance of a license (permit), under which the approved project director, through the immigration officer, will issue a residency permit as provided by the Residence Permits Guideline. For foreign investors, the Tanzania Investment Centre (TIC), the Export Processing Zone Authority (EPZA), and the Zanzibar Investment Promotion Authority (ZIPA) are the key government institutions in charge of organizing, encouraging, promoting, and 
coordinating investment in consideration to the business location. To make foreign investments much easier, the Residence Permits Guideline provides that the Zanzibar government has introduced a new resident permit program for investors looking to purchase property in the country. Several years ago, residence permits were only issued to developers who built commercial and residential real estate or urban infrastructure facilities on the country's territory, such as bridges and piers.

\section{5) Employment and Labor Laws}

The labor legislation includes the Act of 2005 of the Labour-Relations and the Employment Act of 2005 which are in charge of labour-related issues. These Acts conform to international standards, including the ILO convention aimed at protecting worker rights as well set minimum employment standards and covers essential privileges and the safeguard of labour. Under Section 26(2) of Labour Law, among other opportunities, foreigners may get work permits issued by the Commissioner and may employ local and foreign workers for their business. By Sect. 38 of The Employment Act 2005 and Sect. 28(2) of the Zanzibar Labour Act, 1997, the Acts stipulate that foreign investors might from another point of view apply for short-term employment and such other classifications of foreigners as directed in the regulations.

\section{6) Licensing and other regulatory permits}

According to Bennett, and Mneney (2010), the Act of Registration of Business and Licensing sets out the rules governing the licensing of businesses operations and; establishes the free rights to establish private entities, to own property, acquisition, and alienation of the property. In Tanzania (Zanzibar and Mainland) the legal clause stipulates that no business unit can operate without license (depending on where the company is located). BRELA in mainland Tanzania and Zanzibar Business and Property Registration Agency (BPRA) in Zanzibar according to Bennett and Mneney (2010) are relevant bodies or authorities involved in the establishment of a business.

\section{7) Land tenure and related property laws}

Hikmany (September 2015) is on the view that Section 32 of The Land Acquisition Decree 1909 gives the Minister wide discretion to receive requests, analyze, and endorse the land acquisition for 'company purposes', whereas ZIPA as a responsible Law in promoting and protecting investment in Zanzibar by virtue of section 19 is given compliance to acquire private land through the Ministry of Lands as per the Zanzibar Investment Promotion and Protection Act of 2004. Hikmany (2015) made a good point when he stated that in Zanzibar, a private company or an investor can acquire land through the government, but the land can be reclaimed if it is for development purposes.

In addition to that, there is a circumstance where the government is forced to acquire private lands for investment. A good example is in Mpongwe Juma Simba and 8 Others v. Dadi Faki Dadi and Head of Department of Lands and Registration, where the Tribunal established that the acquisition of a farm in Pemba by an Israeli investor was based on coercion and undue influence and 
thus the land was acquired forcefully by the government.

As for general protection however, it is worth noting that, the Zanzibar Legal Framework assures investors the rights to property and protection against expropriations. This is by the Constitution of Zanzibar 1984. This is clearly stated in AG v. Lohay Akonaay \& Joseph Lohay CIVIL APPEAL NO. 31 OF 1994 where the court held sections of the 1992 Act void and not enforceable since it extinguished customary rights to lands; and it declared the compensation as unconstitutionally. The last thing to point out in this part is that, according to Tanzania Foreign Policy and Government Guide, without a Certificate of Incentives given under the responsible authorities, a non-Tanzanian citizen or a private company with a majority of non-Tanzanian shareholders cannot own land in Tanzania even for investment requirements where in Zanzibar ZIPA is the responsible authority.

\section{8) Taxation and fiscal impositions.}

In the words of Beveridge (2000), taxation is probably one of the first considerations for a potential foreign investor. It is frequently one of the factors that make the host state more competitive and hence friendlier to relocation. According to the Tanzanian Constitution, income tax is a Union matter. Thus, all taxpayers in Mainland Tanzania and Zanzibar should register with the Tanzania Revenue Authority (TRA) within 30 days of incorporation or registration as stipulated by Doing Business in United Republic of Tanzania. Naming the main taxes, Wage Indicator (2021) mentioned the corporate taxes of income, withholding taxes on payments of profits, interest, royalties, and natural resources, and rent and individual income taxes as indirect and as direct taxes. Although Tanzania has specific laws addressing investment in special economic zones, most incentives for FDI are provided through tax laws. A case in point is the Income Tax Act 2004. Other laws in this area as per Wage Indicator (2021) is the Finance Act of 1964, the 1998 Act of Value Added Tax, The 1979 Customs Tariff Act No. 1 (Amendment Act) and the Tax Administration and Procedure Act 2009. In the view of Wage Indicator (2021) income tax is applicable to the profits of Tanzanian resident companies and companies that do business through a branch or organization of a foreign company. A foreign conglomerate is considered a resident if it manages and controls the entity's affairs in Tanzania.

\section{9) Dispute settlement; litigation and arbitration.}

Dispute Resolution according to Yannaca (2006) is an essential component of foreign investment legislations owing to the fact that disagreements are unavoidable; and, if not addressed properly, might lead to conflict. In Tanzania (Zanzibar as a part), the Commercial Courts are responsible for this area. Tanzania is also the International Center for Investment Disputes Settlement member (ICSID) and the Multilateral Agency for Investment Guarantee (MIGA). A good example is the dispute of Dowans v. TANESCO Misc. Civil Case No. 8 of 2011, where ICSID stated that "downsizing of foreign emergency power generator, the state's electric utility TANESCO, is worth the US \$65 million". According to IBP USA Tanzania Investment and Business Guide Volume 1, (2013) for- 
eign mining companies complained the government did not honor pledges made in their individual Mining Development Agreements to exempt them from VAT on diesel fuel. In Tanzania Electric Supply Company Limited v. Independent Power Tanzania Limited. ICSID Case No. ARB/98/8, after negotiations failed to produce an amicable settlement, arbitral proceedings were instituted under the auspices of ICSID.

In The Standard Chartered Bank v. The United Republic of Tanzania ICSID Case No. ARB/15/41 ICSID determined that the indirect chain of ownership of Tanzanian borrowers to keep UK claimants in debt does not meet the contractual requirements of the arbitration clause. The court concluded that, while the petitioner had a significant stake in Hong Kong Co., the loan could not be said to be an investment of the petitioner. To benefit from the possibility of arbitration under Article 8 (1), the petitioner must also demonstrate that the investment was made at the petitioner's request, that the petitioner financed the investment, or that the investment was actively and directly under control of the petitioner. This is set out in IBP USA Tanzania Investment and Business Guide Volume 1 (2013).

Usually, according to United Nations (2003) disputes between foreign investors and the Investment Center of Tanzania (TIC) can be worked out using any of the options such as Arbitration, Bilateral or multinational investment protection agreement, or other international methods. To comply with that, the Bilateral Investment Treaties signed and/or ratified by Tanzania shows that Tanzania has entered a total of 20 BITs with other nations including Denmark, Finland, Germany, India, Italy, the Netherlands, Norway, Sweden, Switzerland, the United Kingdom, and Zambia to protect and promote foreign direct investment. Therefore, a foreign arbitration award is also obligatory in Tanzania. In Zanzibar, Submitting of arbitration to which the government is a party is stipulated under Section 1(2) of the Arbitration Decree of 1928.

In what appears to be an irrational decision however, Tanzania's government approved the Public Private Partnership (Amendment) Act, No. 9 of 2018 in September 2018 where as this Act prohibits International Arbitration as a mechanism of settling investor-state conflicts. Ngumi and Sejpal (2021) state that Tanzania's government notified the Dutch government of its intention to terminate the two countries' bilateral investment treaty (BIT), which entered into force on April 1, 2004. The BIT has been in effect for the past 15 years and, if not terminated, would have automatically renewed for another 10 years until 1 April 2029. Thus, as provided under Bilateral Investment Treaties signed and/or ratified by Tanzania, agreements governing public-private partnerships will be controlled by Tanzanian law.

\section{Assessment of China Investments in Zanzibar}

\subsection{Background of China Investments in Zanzibar}

China created a diplomatic connection with Tanganyika and Zanzibar equally as both states gained independence (respectively in 1961 and 1963) as stated by 
Mutch (2012). In this view, according to China Embassy (2008), Tanzania was recognized by China, but bilateral ties for both Zanzibar and Mainland Tanzania were maintained on an equal footing. In Foster et al. (2008), from this diplomatic ties, Tanzania (partly Zanzibar) has received over 100 collaborative projects and programs totaling over the US \$2 billion within the early 1960s whereas, in Moshi \& Mtui (March 2008), most of the earlier aid projects as stated by Monson (2013) were in the shape of turn-key, where the most famous is Tanzania-Zambia-Railway.

According to Rahim (1968) Zanzibar's economic and business policies started to change in mid-1980s and the country adopted the policy of liberalization of trade in 1985. Following privatization plans and broad liberalization in both countries, Daily News (2019) provides that Chinese aid increasingly transitioned during the 1990s' as bilateral support and economic and technical assistance for more flexible loan use. This included the then foreign affairs ministry and the Chinese Ministry of Trade focusing on major industries such as textiles and agriculture. As part of the FOCAC's pledges, China promised to increase the number of zero-duty African exports (Tanzania-Zanzibar included) to China to 466 as propound in Jansson et al. (2009) and in December 1997, the China Investment and Trade Promotion Center was established in Security to help coordinate trade between the two countries.

Upon the visit of China President, His Excellency Xi Jin-ping to Zanzibar in March 2013, and the former President of Zanzibar, Hon. Ali M. Shein's visit to China in May 2013 unfolded more opportunities Cabestan (2016) is on the view that Chinese companies have invested in a number of projects focused on building physical infrastructures such as hospitals, hotels and housing-related projects. In the words on Bilateral Investment Treaties signed and/or ratified by Tanzania, the former Chinese President also encouraged Chinese enterprises to invest in Tanzania and suggested boosting people-to-people exchanges by setting up a Chinese culture center in Tanzania. The current major services that recently commenced by Chinese are the construction of a new airport terminal building, building of commercial seaport in Zanzibar, and the refurbished of football stadium named after Mao Tse Tung.

\subsection{Current Investment Opportunities for China Capital}

The fact that Zanzibar is honored to welcome all potential and existing investors to take advantage of the very lucrative investment opportunities available on these small but attractive islands as stated by Masato (2021), the current legal regime in terms of investment opportunities in Zanzibar for Chinese investors may be addressed in areas that follow:

1) Diplomatic: For Armstrong (2018), China enjoys a special cordial relationship with Zanzibar even before the unification of Zanzibar with Tanganyika for the formation of Tanzania. It was the earliest country to send diplomatic envoy to Zanzibar in February 1964 instantly, after the 1964 revolution. The coun- 
try has delivered uninterrupted bilateral assistance over a sustained period of fifty-five years according to Armstrong (2018), therefore, through these diplomatic ties China has a unique opportunity to negotiate an investment bilateral agreement with Zanzibar in different projects.

2) Investment Incentives: For Abba \& Demarso (2020), investment incentives are a common tool used by investment promotion authorities and are generally used to promote investment. In relation to this, the current legal regime in Zanzibar provides a number of investment incentives for foreign investors in many priority areas. In fact, these incentives are granted by the government to encourage rising amounts of suitable internal and foreign investments. As a result, the incentives offered are competitive and targeted towards areas critical to Zanzibar's economic development. Among the prioritized investments incentives suitable for Chinese investors are as follow;

a) Large scale investments: For Staff (July 2021) the demand large-scale investment and development in residential, industrial, and commercial real estate projects are on the rise in Zanzibar. Until now, The Investments Act of 2018 gave procedures and requirements for Strategic Investment Status (SIS) projects with incentives and allowances to real estate developers, however, not to individuals looking to buy property in the country. Demand has expanded tremendously as a result of the island's strategic location and the ability of non-national investors to purchase property in Zanzibar, offering up more opportunities in the sector. As a result, Zanzibar has been unable to attract significant real estate development, whereas countries such as Mauritius, Dubai, Oman, Singapore, and others have thrived after implementing this strategy as provided by Staff (July 2021). With the launch of the new investor program, foreign buyers of real estate in Zanzibar will now enjoy a number of benefits including real estate while investors are able to acquire a residency permit as an investor. According to Zanzibar Investments Guide 2019-2020 foreign investors are however not required to live in Zanzibar permanently. This seems a great chance for Chinese investors in this area of real estate like housing estates and apartments, shopping malls, buildings for commercial services, and mini cities developments.

b) Access to land: Zanzibar is among the most investor-friendly land acquisition regimes. Under the 1992 Land Law, investors can obtain long-term leases; for the duration of $39,49,66$, or 99 for major projects according to Kasanda and Maganga (2019). Land leased to the investor as per Kasanda and Maganga (2019), once developed may not be repossessed by the government unless it is first authorized by the tribunal of the land upon government submission of justification for the acquisition of such land and secondly, when offsetting fair market price of the development made on it as recompensed by the tribunal of disputes over land. For The Zanzibar Investments Policy, there are also initiatives to create land banks to facilitate the land acquisition for investment purposes. In this regards, since foreigners may legally have access to land in Zanzi- 
bar for investment interests, this is a great opportunity for China to invest from different projects like hotels and shopping malls since the country is still in need of this kind of investments baring in mind the overflow of tourists in the country.

c) Tourism Sector: In Abbas, \& Zhang (2016), there is no single stakeholder in doubt of the advantage that tourists demand can have to the development of the tourism industry in today's business world. Zanzibar boasts pristine beaches and an unspoiled environment. Its unique cultural heritage is unrivaled and its geo-location positions it strategically within an easy reach of many East Africa tourist attractions. According to the Zanzibar Investment Policy (ZIP), up-market resorts, tourism services and supporting business to the industry are among opportunities in the tourism sector that foreign investors especially Chinese may engage into.

d) Agriculture sector: The agricultural sector in Zanzibar includes fisheries, livestock and forestry according to Mdoe (June, 2003). Zanzibar has a high potential for agricultural development, given its comparative advantage of having adequate soils and rainfalls to support crop production according to Mdoe (June, 2003). For Zanzibar Agricultural Transformation Initiative (2009) the great diversity of marine flora and fauna species provide a unique opportunity for the islands to meet the demand for domestic and international markets. However, to Zanzibar Agricultural Transformation Initiative (2009), the Zanzibar's agriculture sector has been plagued by a number of challenges mainly associated with the application of inappropriate farming technologies. Despite the Government policy contained in the Agriculture Sector Policy, the private sector has been unable to adequately participate in the supply of agricultural support services. In light of the above, China investors shall engage in the agricultural areas like farming, fisheries, production and export of cash crops; including fruits like mango and papaya; spices, sea weed and other marine products since this industry plays a major role in the economy. For Vitor and Sackey (2018) a good example of the African country where foreign investments via agricultural sector has made wonders is Ghana because inflows of FDI into Ghana's agriculture sector have a favorable impact on the country's economy.

e) Oil and Gas: In Green, (2018) Zanzibar has a large oil and natural gas potential. The oil and natural gas in Zanzibar's waters have attracted a significant amount of foreign investors willing to explore and extract the most demanding energy resources. The government is very deliberate about walking the talk in the oil and gas sector by increasing internal capabilities, enhancing oil and gas information systems, preparation for Deep Sea multi-client drilling east of Zanzibar, and attracting new investors according to Shariff (2021). Therefore, for Shariff (2021) the development of the oil and gas sector and the diversity of Zanzibar's economy will actually require successful relationships between the government and private sectors. Taking advantage in this situation and since Zanzibar has recently opened its doors to more investments, China may engage in 
this area especially on drilling and storage of oil and gas. It is worth noting that, currently Zanzibar has oxygen deficiency, thus, the country is in great need of gas due to overcrowding of Covid-19 patients needing gas in the main hospital (Mnazi Mmoja) as written by IPP Media. In line of this, Chinese companies are welcomed to negotiate with the government in engaging in this area for investments especially now where Zanzibar has discovered its own gas needing to be extracted.

f) Blue economy: The blue economy in all of its forms is vital to Zanzibar's and Tanzania's socioeconomic development. However, fisheries and Marine products sector are more crucial when it comes to foreign investments as provided by Feidi (2005). With scarce marine materials and biodiversity, Zanzibar Island offers infinite potential for fisheries development. In Budeba (2016), Zanzibar Fort, located at the intersection of resources of marine and biodiversity, with illimitable potential for the improvement of the fishing industry. Foreign investors including Chinese are invited to invest in large-scale and deep-sea fishing ventures. In line with that, investors are free to select areas appropriate for investing in the offshore fishery; Fish Processing \& Canning; Sea-weed processing; Marine product dispensation and, Aquaculture. Another important note is that, since the fishing boats employed in fishing process are small, the majority of the fishing takes occurring within 5 miles of the beach. Thus, huge fishing crafts production is another good investment opportunity for Chinese investors. Investment in these industries will stimulate commerce while also raising government revenue and enhancing the lives of Zanzibaris.

g) Free Economic Zones: Although the range of investment opportunities is wide, in my opinion the focus areas among the government's preferred activities in which Chinese investors may engage in regards to free economic zones include the following: Shoes and leather goods, Metal work and engineering, furniture and joinery, pharmaceutical-based chemical goods, electronics assembly, food processing and fruit canning, seaweed processing, and marine product processing are all examples of industries that use metal work and engineering. This is all due to their development impact as stated by Davies (2013). As a result, since China has become Africa's largest trading partner, and there is clear evidence that most African businessmen (including Zanzibaris') prefer to buy their business products from China (including shoes, bags, and electronics assembly) over other countries around the world, it is better for Chinese investors to bring China in Zanzibar by investing in free economic zones in those proposed areas.

\section{Challenges on the Current Investments Opportunities}

Much is already understood about what factors should encourage private investment. To thrive, the foreign investments involves a stable and predictable investment climate, which is provided by transparent and accountable government, strict enforcement of the rule of law, skilled and productive labor force, 
affordable and accessible infrastructure, and intelligent infrastructure. Point to note is that Zanzibar acquires almost all of the above mentioned factors. But yet there are some challenges for the current opportunities as stated here under which are divided into three categories: cultural challenges, legal challenges, and administrative and operational challenges.

\subsection{Cultural Challenges}

\section{1) Religious}

Tourism has long played a significant role in the development of islands according to Omission on Sustainable Development (1996). In Bojanic, Warnick, and Musante, (2009) this is in particular, the case for Developing States Small Island (SIDS), where tourism has become an essential component of economic development. Under the Zanzibar culture which is based on the Islamic religion as observed by Ziddy (2013), investors have to follow such cultural norms. For instance, gambling is prohibited under Islam; therefore investors must exclude gambling when investing in hotels though according to the investors, gambling is among the hotel attraction and the source of income. Alcohol consumption is also restricted under The Alcohol Control Bill 2020. However, during interview with Oscar John who is a regular beer customer in Zanzibar, he was on the view that, "since Zanzibar depends on part of its income from tourism, having in place tough legislation on liquors is probable to hold a negative effect in the Isles economy".

Further, Thomson (2017) has reminded foreigners who are visiting Zanzibar whether for tourism or investment related to respect Islamic culture of fasting by not dine in public and they should dress modestly. They can however buy food on their own and eat it when, and where they like but not in public. They can have lunch and cocktails on the beach resorts because they are allowed to serve foreigners.

\section{2) Language and Culture}

Rwegelera (2014) is on the view that each country does have its own way to do things that distinguishes it from other nations and that, language is primarily responsible for this coition. Language is among the major issues in respect to negotiations with trade partners from other cultures according to Cardenas (2020). Foreign partners in Deari, Kimmel \& Lopez (2008) may easily misinterpret one another if negotiating without knowledge of each other's assumptions and values. For instance, some people would be insulted to be tended to by their first names and some might believe that using informal styles and first names would signal to the partners that they are trusted as per Deari, Kimmel \&, Lopez (2008). In Zanzibar since the majority speak their own languages and only few with a bit of English, it makes interacting with international investors difficult especially when foreign investors work with government officials who do understand neither English nor investor's own language. It is more challenging when investor asking for some information from local people as stated by for- 
eign investor Hou of Asia \& Africa International Investment PTY LTD. Dealing with a linguistic issue, China is poised to address this concern by allowing the Swahili language to be taught in some of its Universities like Beijing Foreign Languages University, Shanghai International Studies University and Zhengzhou University of Aeronautics (ZUA).

\subsection{Legal Challenges}

\section{1) Limited security of tenure}

Foreigner's Guide to Property Investment in Zanzibar (2020) provides that investment security is limited because land tenure in Zanzibar is only available on leasehold for foreign investors, in contrast to other African countries, such as South Africa, Namibia, Botswana, and Kenya, which allow the freehold and have attracted considerable private investment in areas protected as provided in A Foreigner's Guide to Property Investment in Zanzibar (December 9, 2020). Land leases issued by virtue of the 1986 Act of Investment Protection can be reversed by the State with relative ease, thus further weakening long-term security of tenure, and this leads to insecurity for foreign investors.

\section{2) Inadequate Regulatory Framework}

The investment framework in Zanzibar is unnecessarily complicated and obsolete to some extent as provided in Foreigner's Guide to Property Investment in Zanzibar (2020). In response to this, Foreigner's Guide to Property Investment in Zanzibar (2020) presents that the clarity for investors is moreover limited by the fact that foreign investment regulations by sector and size threshold are broken up into many different pieces rather than being incorporated into a single piece of legislation which can simplify the understanding as well as the investments registrations procedures. This lack of institutional coherence, which often leads to ineffective implementation of investment policies and regulations, partly stems from the absence of overarching national investments strategy as pointed out by OECD (2013).

Moreover, there is no specific Arbitration Act in Zanzibar. Instead, the arbitration is administered by different laws such as Civil Procedure Decree, the Zanzibar Industrial Court Act 1994, and other contracts related laws which make arbitration difficult compared to Mainland Tanzania where there is an Arbitration Act to administer arbitration. In line of this, Jurisic and Wietzore (2021) stipulates that, on 7 February 2020, the National Assembly of Tanzania passed a new Arbitration Act which only applies in Mainland Tanzania and thus not to Zanzibar the second entity of the United Republic of Tanzania.

\section{3) Corruption, Bureaucracy and Delaying on Administration of Justice}

For Tanzania Investment Centre's Social Accountability Session Report (2012), the goal of judiciaries to enable the resolution of commercial disputes in a timely, efficient, and effective manner, ensuring that the judiciaries act as catalysts for economic growth, is the driving force behind the creation of commercial courts. However, the same report indicates that, in Tanzania (Zanzibar as a 
part) corruption, bureaucracy and slow decision-making processes are among the challenges that face investments in the country. Courts are regarded lacking capability, cases backlogged, inefficient, capable of influence and easily corruptible. Companies can thus feel vulnerable when doing business in Tanzania and Zanzibar. As corruption in the legal and court systems has not yet been prosecuted and punished, the report indicates that the image of Zanzibar as an efficient, secure and profitable location for foreign investment has been affected for somehow.

Additionally, despite the existence of legal mechanisms provided in this paper, the Investment Climate Statements (2020) points out that, Tanzania foreign investors have been claimed that the government itself does not always honor its agreements. One high-profile example is a U.S.-based energy company that filed an ICSID arbitration application seeking USD 561 million for alleged breach of contract where as the dispute is still ongoing.

\subsection{Administrative and Operational Challenges}

\section{1) Outdated Tax Payment Methods}

As pointed out by Doing Business in Zanzibar (2010), paying taxes in Zanzibar is difficult for investors due to the vast number of institutions involved in tax collection. Taxes must be paid to the Tanzania Revenue Authority (TRA), the Zanzibar Revenue Board (ZRB), and local governments separately. The procedure is more complicated since there is a chain of procedures for the payment. In addition, as per Ratansi, Lina (2020), TRA has implemented online filing of tax returns in Zanzibar which increases voluntary compliance, saves time, and improves efficiency in the tax administration regime. However, the system has some flaws, such as outdated tax forms that missed key details and changes in the law, a time limit for online filling, and there is no clear workaround for regions where connectivity is a problem as to whether manual filling will be used instead and whether they will be updated online if used.

\section{2) Poor infrastructure}

Inadequate infrastructure discourages foreign and domestic investment in Zanzibar and Tanzania at large as stated by OECD (2013). Enabling infrastructure for production, transport, processing, and marketing is not integrated in a multi-modal manner. Electricity also appears to be the worst-performing infrastructure sub-sector.

\section{Conclusion and Recommendations}

Tanzania, in consonance with the Government officials, welcomes foreign direct investment (FDI) as it follows its agenda for mechanization and development. The present legislation for investment has played a significant role in boosting domestic and foreign investment, but it could be changed for the better in some areas, particularly when it comes to land tenure, foreign investor access regulations in some sectors, investment incentives, and intellectual property rights 
protection. Investors and potential investors are aware that the main investment challenges explained inter alia including ambiguous tax policies, local material requirements, and the government's mistrust of the private sector which has led to a decline in profits. To respond to these challenges, the following are recommended for Zanzibar government as well foreign investors:

1) For the Government.

a) Zanzibar should improve its investment climate. In line of this, Zanzibar should learn better practice from China by having a single document in regards to foreign investments instead of having laws in piecemeal. A provided by Xie, Voon and Leo (2020) and Zhang and Tsoi (20th March 2019), China has created The Foreign Investment Law of the People's Republic of China of 2019 replacing The Sino-Foreign Equity Joint Ventures Law, The Law of Wholly Foreign-owned Enterprises, and the Law of the People's Republic of China on Sino-Foreign Cooperative Joint Ventures, which is the best approach for safeguarding foreign investments.

b) The government should focus more on strengthening investment climate by revising existing laws and adopting new legislations for greater protection for foreign investors especially updating laws that have been in effect for many years.

c) Zanzibar should review its tax and trade regimes in order to mainstream and simplify their administration for improved efficiency in private sector. According to Doing Business in Zanzibar 2010 Report, one way of improving tax compliance is to simplify the payment system. Thus Zanzibar should work in this recommendation.

d) Zanzibar has to adopt "The Overseas-Investments Guidance Catalogue" to simplify foreign investment information with China as a model. China's specific foreign investment objectives are primarily described in this Catalogue with the most recent significant modification in 2020 and implemented on early 2021. Zheng (2021) has pointed out that in that catalogue, economic sectors where the foreign nature investments were "encouraged," "controlled," and "prohibited", underwent a great change. In (2013 Investment Climate Statement), a new list the industries list encouraged for foreign investment in which investments receive preferential treatment still maintained, while all special management measures (SMM) for admission, including restrictions and prohibitions have been moved to a negative list.

e) Encourage foreign investors to participate in Corporate Social Responsibility. This should be done in parallel with increasing the capacity of indigenous governments to identify priorities and propose project proposals.

f) Using local laws to resolve conflicts involving international capital is likely to provide substantially less protection for foreign investors especially when it is acknowledged that emerging economies such as Tanzania require bilateral agreements to attract and promote foreign direct investments. As a result, if Tanzania intends to use local laws in this regard, such agreements should be carefully drafted to ensure the host nation's interests are protected, including re- 
viewing and introducing new laws and regulations to adapt to the changing business environment. Also, Tanzania should think inside the box on the kind of BITs to prohibit.

\section{2) For investors.}

a) Chinese investors should have specialist legal counsel who knows Tanzania well and particularly Zanzibar to assist all the way through the investment procedures.

b) As a more general matter, many investment disputes could be avoided if investors could not take unfair advantage of low-regulation environments until the State reacts or, rather, over-reacts. Therefore, Chinese investors must observe this statement to avoid any kind of legal risk such as disputes.

c) A lasting investor who sensibly wants to entangle a project into a legally underdeveloped state will not only learn but also help to establish, the rules for the project inauguration. In the line with this statement, the Chinese government and investors particularly, should contribute to the legal development by working with local governments to help design rules that fit their complex projects/investments. This kind of cooperation is ideal when it gives the investor legal security and helps the local government to build its own legal institutions.

\section{Conflicts of Interest}

The authors declare no conflicts of interest regarding the publication of this paper.

\section{References}

(2002). African Democracy Encyclopaedia Project. https://www.eisa.org/wep/zan5.htm

(2002). Tanzania Human Rights Jurisprudence. University of Minnesota, Human Rights Library, UN-Habitat 69.

(2010). Doing Business in Zanzibar. https://openknowledge.worldbank.org/bitstream/handle/10986/13439/74678.pdf;jsessio nid=2535DC215BAA26D25B9277455E3D3397?sequence

(2020, December 28). Corporate Registration Guide, Zanzibar. https://ark.co.tz/corporate-registration-guide-zanzibar/?print=pdf

(2020, December 9). A Foreigner's Guide to Property Investment in Zanzibar. https://newslo.com/a-foreigners-guide-to-property-investment-in-zanzibar

Abba, B., \& Demarso, Y. (2020). The Legal Framework Governing Investment Areas and Incentives in Ethiopia: A Critical Appraisal. Beijing Law Review, 11, 740-758. https://doi.org/10.4236/blr.2020.113045

Abbas, A. O., \& Zhang, X. F. (2016). Impact of Foreign Direct Investment on Employment Evidence: Zanzibar Tourism Industry. International Journal of Economics, Finance and Management Sciences, 4, 250-256. https://doi.org/10.11648/j.ijefm.20160405.13

AG v. Lohay Akonaay \& Joseph Lohay. CIVIL APPEAL NO. 31 OF 1994.

Ajl, M. (2020). Reclaiming Africa: Scramble and Resistance in the 21st Century. Review of African Political Economy, 47, 1-3. https://doi.org/10.1080/03056244.2020.1788362

Armstrong, J. D. (2018). Revolutionary Diplomacy: Chinese Foreign Policy and the 
United Front Doctrine. University of California Press.

Awunyo-Vitor, D., \& Sackey, R. A. (2018). Agricultural Sector Foreign Direct Investment and Economic Growth in Ghana. Journal of Innovation and Entrepreneurship, 7, 15. https://doi.org/10.1186/s13731-018-0094-3

Bennett, T., \& Mneney, D. (2010). Zanzibar-Public Financial Management Performance Report.

Bevan, D. et al. (1987). East African Lessons on Economic Liberalization. Gower.

Beveridge, F. (2000). The Treatment and Taxation of Foreign Investment under International Law: Towards International Disciplines. Manchester University Press.

Bojanic, D. C., Warnick, R., \& Musante, M. (2009). An Evaluation of the Relative Importance of Tourism for Islands. Lender School of Business, Quinnipiac University. https://scholarworks.umass.edu/ttra

Budeba, Y. L. (2016). The Tanzanian Fisheries Sector: Challenges and Opportunities. Royal Danish Embassy.

https://www.coursehero.com/file/79349212/The-Tanzanian-Fisheries-Sector-Challenge s-and-opportunitiespdf/

Bukuku, E. S. (1993). The Tanzania Economy: Income Distribution and Economic Growth (p. 43). Praeger.

Bureau of Economic and Business Affairs (2013, February). Investment Climate Statement. https://2009-2017.state.gov/e/eb/rls/othr/ics/2013/204744.htm

Cabestan, J.-P. (2016). Tanzania-China all Weather Friendship from Socialism to Globalization: A Case of Relative Decline. SUNScholar Research Repository. http://hdl.handle.net/10019.1/100545

Cardenas, L. (2020, May 14). International Negotiation: Overcoming Cultural Barriers in Negotiations and the Importance of Communication in International Business Deals. https://www.pon.harvard.edu/daily/international-negotiation-daily/bridging-the-cultur al-divide-in-international-business-negotiations

China Embassy (2008). Political Relations between China and Tanzania and Ministry of Foreign Affairs of the PRC. http://tz.china-embassy.org/eng/ztgx/zz/t427908.htm

China's Economic Rise: History, Trends, Challenges, and Implications for the United States. https://www.everycrsreport.com/reports/RL33534.html

Constitutional History of Tanzania.

https://constitutionnet.org/country/tanzania-country-constitutional-profile

Customs Tariff Act (No. 1 of 1979) (Amendment Act).

Daily News (2019). Shein Opens Revamped Mao-Tse-Tung Stadium. https://dailynews.co.tz/news/2019-01-055c3081307e7d1.aspx

Davies, K. (2013). China Investment Policy: An Update. OECD Working Papers on International Investment, 2013/01, OECD Publishing.

Deari, H., Kimmel, V., \& Lopez, P. (2008). Effects of Cultural Differences in International Business and Price Negotiations - A Case Study of a Swedish Company with Operations in e.g. South America. International Marketing Strategy FE3014 VT-08. Växjö.

Doing Business in United Republic of Tanzania. https://rexattorneys.co.tz/wp-content/uploads/2020/04/Doing-Business-in-Tanzania-C lean-Ver.-08.04.2020-converted.pdf

Dowans v. TANESCO Misc. Civil Case No. 8 of 2011.

Employment Act (No. 11 of 2005).

Feidi, I. H. (2005). The Fisheries of Zanzibar: Potential for New Investments. NAGA, 
World Fish Center Quarterly, 28, 37-40.

Finance Act of 1964.

Foreign Investment (Protection) Act. 1963.

Foster, A., Butterfield, V., Chen, W., Chuan and Pushak, N. (2008). Building Bridges: China's Growing Role as Infrastructure Financier for Sub-Saharan Africa. Public-Private Infrastructure Advisory Facility, World Bank.

Gabagambi, D. M. (2013, May). Tanzania's Growth Experience Following Economic Reforms: Comparative Perspectives with Vietnam. International Journal of Humanities and Social Science, 3, 97.

Gagné, G. (2019). The Canadian Policy on the Protection of Foreign Investment and the Canada-China Bilateral Investment Treaty. Beijing Law Review, 10, 361-377. https://doi.org/10.4236/blr.2019.103021

Gestrin, M. (2006). Policy Framework for Investment: A Review of Good Practices. Investment Division. Directorate for Financial and Enterprise Affairs.

Green, J. (2018, November 27). Chinese Oil Dripping Ships Dock in Zanzibar. https://theexchange.africa/economic-growth/energy/Chinese-oil-dripping-ships-dock-i n-zanzibar

Hikmany, A.-N. (2015, September 2). The Many Land Acquisition Laws of Zanzibar: Is There an Innermost Objective? In International Conference on Advanced Research in Business and Social Sciences 2015. Ahmad Ibrahim Kulliyyah of Laws, International Islamic University Malaysia, 50728. https://ssrn.com/abstract=2687652 https://doi.org/10.2139/ssrn.2687652

IBP USA (2013). Tanzania Investment and Business Guide Volume 1. Strategic and Practical Information. International Business Publications.

Income Tax Act 2004.

Investment Climate Statements 2020: Tanzania. https://www.state.gov/reports/2020-investment-climate-statements/tanzania

Jansson, J., Kiala, C., Liu, H. F., Hon, T., \& Burke, C. (2009). Evaluating China's FOCAC Commitments to Africa and Mapping the Way Ahead. Coming Publication, Centre for Chinese Studies.

Jurisic, K., \& Wietzorek, M. (2021, April 21). The First Year of Tanzania's 2020 Arbitration Act. University of Munich and Taylor Wessing. Kluwer Arbitration Blog. http://arbitrationblog.kluwerarbitration.com/2021/04/21/the-first-year-of-tanzanias-20 20-arbitration-act

Karume, S. (2006). Dilemmas of Political Transition: Towards Institutionalisation of Multiparty Democracy in Tanzania. NORAD and OSIS.

Kasanda, P. A. S., \& Maganga, M. (2019, March 14). Land Acquisition in Tanzania: What Foreign Investors Should Know. Clyde \& Co LLP. https://www.lexology.com/library/detail.aspx?g=ac76bd9d-e19b-43d7-8e66-dee181f53e 3f

Loimeier, R. P. L. (2009). The Politics of Islamic Education in 20th Century Zanzibar.

Maina, C. P. (1988). The 1986 Investment Protection Act of Zanzibar. ICSID Review-Foreign Investment Law Journal, 3, 338-351.

https://doi.org/10.1093/icsidreview/3.2.338

Maina, C. P. (1994). Foreign Investments in Tanzania: The Mainland and Zanzibar. Friedrich Ebert Stiftung.

Masato, M. (2021, August 11). Zanzibar to Open 50 plus Small Islands for Investors. Dai- 
ly News.

Mdoe, N. S. Y. (2003, June). Survey on Livestock and Agriculture Development in Zanzibar, Post-Tsetse Eradication: Socio-Economic Study. Department of Agricultural Economics and Agribusiness Sokoine University of Agriculture.

Ministry of Trade and Industry. Zanzibar Industrial Policy (2019-2029). https://www.zanrevenue.org/uploads/znz investment policy 2007.pdf

Mittelman, J. H. (1981). Underdevelopment and Transition to Socialism: Mozambique and Tanzania (p. 169). Academic Press.

Monson, J. (2013). Remembering Work on the Tazara Railway in Africa and China, 1965-2011: When “New Men” Grow Old. African Studies Review, Piscataway, 56, 45-64. https://doi.org/10.1017/asr.2013.5

Mosedale, J. (2011). Political Economy of Tourism: A Critical Perspective (p. 162). Routledge. https://doi.org/10.4324/9780203835876

Moshi, H., \& Mtui, J. (2008). Scoping Studies on China-Africa Economic Relations: The Case of Tanzania. http://hdl.handle.net/10419/93166

Mpongwe Juma Simba and 8 Others v. Dadi Faki Dadi and Head of Department of Lands and Registration.

Neerso, P. (1972). Some Aspects of Tanzania's Policies on Private Foreign Investments (p. 17). Institute for Development Research.

Ngumy, D., \& Sejpal, S. (2021). Tanzania Terminates Bilateral Investment Treaty with the Netherlands.

https://www.africalegalnetwork.com/tanzania/news/legal-alert-tanzania-terminates-bil ater-

al-investment-treaty-netherlands/\#: :text=On\%2030\%20September $\% 202018 \% 2 \mathrm{C} \% 20 \mathrm{~h}$ ours,(BIT)\%20between\%20both\%20nations

Nyerere, J. K. (1966). Freedom and Unity (p. 209). Oxford University Press.

OECD (2002). Global Forum on International Investment Attracting Foreign Direct Investment for Development. FDI and Domestic Private Sector Development in Africa "The Experience of Tanzania".

OECD Investment Policy Reviews: Tanzania 2013.

Omission on Sustainable Development (1996). Progress in the Implementation of the Programme of Action for the Sustainable Development of Small Island Developing States. Report of the Secretary-General. Fourth Session.

Peter, C. M., \& Mwakaje, S. J. (2004). Investments in Tanzania: Some Comments, Some Issues. Dept. of International Law, University of Dar es Salaam.

Rahim, B. (1968 June). Legislative Implementation of the Arusha Declaration. East African Law Journal, 4, 183.

Rainer, M. B., \& Peter, C. M. (1989). Administration of Justice in Tanzania and Zanzibar: A Comparison of Two Judicial Systems in One Country. The International and Comparative Law Quarterly, 38, 395-412. https://doi.org/10.1093/iclqaj/38.2.395

Ratansi, L. (2020, August 25). Electronic Filing of Tax Returns. https://www.rsm.global/tanzania/insights/consulting-insights/electronic-filing-tax-retu $\underline{\text { rns-0 }}$

Residence Permits Guideline.

https://eservices.immigration.go.tz/online/permit/guidelines

Rugumamu, S. (1988). State Regulation of Foreign Investment in Tanzania: An Assessment. Journal Storage, 13, 5-28. 
Rwegelera, M. K. (2014). The Effect of Globalization on Tanzanian Culture: A Review. The Open University of Tanzania.

Saïd, M. D. (2013, November 19). Chinese Investment in Africa (Part 1). http://www.bsi-economics.org/219-chinese-investment-in-africa-part-1

Shariff, O. (2021, July 20). Oil \& Gas: A Key Sector in the Diversification of Zanzibar's Economy.

https://www.ecofinagency.com/public-management/2007-42851-oil-gas-a-key-sector-i n-the-diversification-of-zanzibar-s-economy

Staff (2021, July). The Government of Zanzibar Has Launched a New Tax and Residency Programme for Expats to Live and Invest in the Tanzanian Island.

https://furtherafrica.com/2021/07/08/zanzibar-luring-investors-with-new-tax-and-resi dency-scheme

Standard Chartered Bank v. The United Republic of Tanzania (ICSID Case No. ARB/10/12), Award, 2 November 2012, paras. 196-197.

Sueiman, R. (2021, August 28). Hospitali ya Mnazi Mmoja Yazidiwa Corona (Mnazi Mmoja Hospital Overcrowded Corona).

https://www.ippmedia.com/sw/habari/hospitali-ya-mnazi-mmoja-zanzibar-yazidiwa-c orona

Suhonen, R. (2009). Mapinduzi Daima-Revolution Forever: Using the 1964 Revolution in Nationalistic Political Discourses in Zanzibar. Master's Thesis, Institute for Asian and African Studies University of Helsinki.

Tanzania Electric Supply Company Limited v. Independent Power Tanzania Limited. ICSID Case No. ARB/98/8, Final Award 12th July 2001

Tanzania Investment Centre (2012). Report on Social Accountability Session. The Contribution of Foreign Direct Investment to Local Economy in Tanzania: Achievements, Challenges and Prospects.

Tax Administration and Procedure Act 2009.

The Tanganyika Gazette, 1963.

The United Republic of Tanzania (2002). United Nations Conference on Trade and Development. Investment Policy Review. UNCTAD/ITE/IPC/Misc. 9.

The Zanzibar Industrial Property Act No. 4 of 2008.

Thembi Mutch (2012). China in Africa Win-Win? Historical and Cultural Bonds. https://www.jamiiforums.com/threads/china-in-east-africa-win-win.305206/

Thomson, S. (2017, February 9). 10 Tips for Enjoying Zanzibar during Ramadan. https://theculturetrip.com/africa/tanzania/articles/10-tips-for-enjoying-zanzibar-durin g-ramadan

United Nations (2003). United Nations Conference on Trade and Development. Dispute Settlement, UNCTAD/EDM/Misc.232/Add.2.

United Nations (2004). United Nations Conference on Trade and Development. International Investment Agreements: Key Issues Volume I. United Nations.

Usiri, G. (2014). The Effects of Foreign Direct Investment on Economic Growth: The Case of Tanzania. Master's Thesis, Mzumbe University.

Wage Indicator (2021). Business Tax and Levies. Mywage.org/Tanzania.

Xie, A. L., Voon, F., \& Luo, C. Y. (2020, March 16). China's "New" Foreign Investment Law. Asia Corporate Alert.

Yannaca-Small, K. (2006). Improving the System of Investor-State Dispute Settlement. OECD Working Papers on International Investment, 2006/01, OECD Publishing. 
Zanzibar Agricultural Transformation Initiative (2009). Zanzibar Agricultural Transformation for Sustainable Development, 2010-2020 for Agricultural Productivity, Food Security and Sustainable Livelihood.

Zanzibar Business and Property Registration Agency, Company Registration. https://www.bpra.go.tz/index.php/registration/company-registration

Zanzibar Constitution of 1963.

Zanzibar Investment Policy (ZIP).

Zanzibar Investments Guide 2019-2020. https://www.zipa.go.tz/pdf/guide2020.pdf

Zanzibar Labour Act, 1997.

Zervos, N., Ndyetabura, J., Mramba, C. et al. (2020, October 1). Establishing a Business in Tanzania.

https://uk.practicallaw.thomsonreuters.com/7-562-2905?transitionType=Default\&cont extData $=($ sc. Default $) \&$ firstPage $=$ true

Zhang, Z. A., \& Tsoi, V. (2019, March 20). China Adopts New Foreign Investment Law. https://www.whitecase.com/publications/alert/china-adopts-new-foreign-investment-1 aw

Zheng, Y. (2021). China's New Foreign Investment Law and Its Contribution towards the Country's Development Goals. The Journal of World Investment \& Trade, 22, 388-428.

Ziddy, I. (2013). Western Tourism in Zanzibar: Cultural and Religious Implications. State University of Zanzibar (SUZA).

https://dergipark.org.tr/tr/download/article-file/230559 